\title{
Stress of Type 2 Diabetes Mellitus Patients in Implementation Self Care Management
}

\author{
Andri Setyorini*, Supriyadi \\ Nursing Study Program, Surya Global Institute of Health Science, Indonesia \\ *andrisetyo04@gmail.com
}

\begin{abstract}
Diabetes has now become a common disease and we can find it anywhere, even diabetes has become the 4 th leading cause of death in the world. The incidence of Diabetes Mellitus (DM) continues to increase and type $2 \mathrm{DM}$ is the most cases of all DM cases. DM disease cannot be cured, but it can be managed by complying with the 4 pillars of DM management which should ideally be carried out properly. This certainly can lead to boredom and stress because they have to comply with the recommended DM management program throughout their life. The purpose of this study is to explore the description of stress in patients with type 2 diabetes in the implementation of self-care management. This study uses a descriptive qualitative approach that is carried out in a natural setting (natural conditions). Primary data sources and data collection techniques use in-depth interviews, participant observation and documentation. Participants in this study were 5 DM type 2 patients with the determination of participants using purposive sampling technique. Data analysis used qualitative content analysis to interpret the data descriptions related to stress in patients with type 2 diabetes. The results of the data analysis that has been carried out on 5 participants, there are four main themes that illustrate stress in patients with type 2 diabetes in the implementation of self-care management including: 1) perceived complaints, 2) comorbidities, 3) dietary restrictions, and 4) psychosocial factors. Therefore, sufferers need to always understand that stress is a trigger for an increase in blood glucose levels which should be controlled with proper coping.
\end{abstract}

Keywords: Type 2 Diabetes Mellitus, Self Care Management, Stress 


\section{STRADA Jurnal Ilmiah Kesehatan}

DOI: $10.30994 /$ sjik.v9i2.419

ISSN: 2252-3847 (print); 2614-350X (online)

Vol.9 No.2 November 2020 Page.1250-1257

\section{BACKGROUND}

Diabetes is a chronic disease that is very dependent on the behavior and lifestyle changes of each individual. Diabetes has now become a common disease and we can find it anywhere, even diabetes has become the 4th leading cause of death in the world(American Diabetes Association 2010). WHO predicts an increase in the number of people with diabetes in Indonesia from 8.4 million in 2000 to around 21.3 million in 2030 (WHO 2016).

Based on the latest data from Basic Health Research (Riskedas) in 2018, the prevalence of diabetes in Indonesia has increased from 6.9 percent in 2013 to 8.5 percent in 2018. Then the prevalence of diabetes mellitus based on the doctor's diagnosis in the population aged more than 15 years reached 4.79 percent. This figure even increased compared to the results of research five years earlier or in 2013, namely 3.4 percent (Kementerian Kesehatan RI 2018).

This disease cannot be cured, but can be managed by complying with the 4 pillars of DM management which ideally must be carried out properly. However, it is often an obstacle in diabetes care because it requires compliance and motivation from the patient himself. This of course can lead to boredom and stress because they have to adhere to the recommended treatment and treatment programs throughout their life (Setyorini 2017).

Stress is the inability to overcome the threats faced by human mental, physical, emotional, and spiritual, which at one time can affect human physical health. Emotional stress that occurs in diabetics can certainly increase blood sugar levels through increased sympathoadrenal stimuli.

Meanwhile, if you look back at the complications that can be experienced by uncontrolled DM

patients, it is possible that they are very at risk of experiencing complications ranging from acute to chronic complications(Smeltzer, S, C \& Bare, B 2010).

The stress that arises and the duration of stress are determined by the various difficulties experienced by patients during the therapy program, so that the way the sufferer handles stress when undergoing a treatment program especially for patients with DM can affect their success in adhering to the therapy program and controlling blood sugar levels (Septiar and Utami 2015).

The results of Survilends by Riskesdas 2018 also stated that the reasons for DM patients not regularly taking anti-diabetes drugs were very diverse, where as many as $50.4 \%$ of DM patients argued that they felt cured, so this made them ignore the importance of good DM self-management (Kementerian Kesehatan RI 2018). Therefore, sufferers need to always understand that stress is a trigger for an increase in blood glucose levels which should be controlled with proper coping (Widodo 2013).

The purpose of this study is to explore the description of stress in patients with type 2 diabetes in the implementation of self-care management. Than with the hope that later it can provide the right coping solutions to minimize complications.

\section{METHODS}

This study uses a descriptive qualitative approach with in-depth interviews and observation as data collection methods. The study was conducted by directly describing and not manipulating the phenomena that occur regarding stress in Type $2 \mathrm{DM}$ patients in the implementation of self care management (Sandelowski 2000). This research was conducted from July to October 2020.

Participants in this study were 5 patients with type 2 diabetes who were previously 


\section{STRADA Jurnal Ilmiah Kesehatan}

DOI: $10.30994 /$ sjik.v9i2.419

ISSN: 2252-3847 (print); 2614-350X (online)

Vol.9 No.2 November 2020 Page.1250-1257

selected using purposive sampling technique (Nursalam, 2015). The instrument used in this study was a semi structured interview guide with data analysis using qualitative content analysis to interpret data descriptions related to stress in patients with type 2 diabetes (Creswell John W 2014) . This study has also passed ethics with reference number 01.17 / KEPK / SSG / VII / 2020 on July 17, 2020.

\section{RESULTS}

Characteristics Of Respondents By age, gendre, profession, last education, long suffering from DM, recent blood sugar levels

Data related to the description of partisipants based on age, gendre, profession, last education, long suffering from DM, recent blood sugar level

Table 1. Characteristics Of Respondents By age, gendre, profession, last education, long suffering from DM, recent blood sugar levels

\begin{tabular}{llllllc}
\hline Initial & $\begin{array}{l}\text { Gendre } \\
(\mathbf{M} / \mathbf{F})\end{array}$ & $\begin{array}{l}\text { Age } \\
\text { (years } \\
)\end{array}$ & Profession & $\begin{array}{l}\text { Last } \\
\text { Education }\end{array}$ & $\begin{array}{l}\text { Long } \\
\text { Suffering } \\
\text { from DM }\end{array}$ & $\begin{array}{l}\text { Recent } \\
\text { Blood Sugar } \\
\text { Levels } \\
\text { (mg/dlg) }\end{array}$ \\
\hline P1 & F & 60 & Farmer & $\begin{array}{l}\text { Elementary } \\
\text { School }\end{array}$ & 4 years & 132 \\
\hline P2 & F & 60 & Farmer & $\begin{array}{l}\text { Elementary } \\
\text { School }\end{array}$ & 3 years & 305 \\
\hline P3 & F & 63 & Farmer & $\begin{array}{l}\text { Elementary } \\
\text { School }\end{array}$ & 7 years & 117 \\
\hline P4 & F & 62 & $\begin{array}{l}\text { Entrepreneu } \\
\text { rs }\end{array}$ & $\begin{array}{l}\text { Elementary } \\
\text { School }\end{array}$ & 12 years & 355 \\
\hline P5 & M & 60 & Entrepreneu & $\begin{array}{l}\text { Junior High } \\
\text { rs }\end{array}$ & School years & 371 \\
\hline
\end{tabular}

The characteristics of the five participants in this study can be described as follows: participants in the study were 1 male and 4 female with age 60 years and over. 2 participants work as farmers and 3 as entrepreneurs. Based on the education level, 4 participants with the latest elementary school and 1 person with the latest junior high school. Based on the length of suffering from diabetes, there were 4 participants who had diabetes for less than 10 years and 1 participant who had suffered from diabetes for more than 10 years. Based on the results of the last blood sugar check, it can be seen that 3 participants had blood sugar when it was above $200 \mathrm{mmHg}$ and there were 2 participants who had blood sugar below 200 so that it could be said to have been controlled even though it was still above normal values.

\section{Results of Data Analysis}

Based on in-depth interviews and data analysis that has been carried out on 5 participants, there are four main themes that illustrate stress in patients with type 2 diabetes in the implementation of self-care management, including because: 1) Perceived complaints, 2) Comorbidities, 3) Dietary restrictions, and 4) Psychosocial factors. 


\section{STRADA Jurnal Ilmiah Kesehatan}

DOI: $10.30994 /$ sjik.v9i2.419

ISSN: 2252-3847 (print); 2614-350X (online)

Vol.9 No.2 November 2020 Page.1250-1257

\section{1) Perceived Complaints}

Based on the results of in-depth interviews conducted with 5 participants, data was obtained that the picture of stress in type $2 \mathrm{DM}$ patients was related to the complaints they felt, where almost all participants had complained that their body was sometimes weak and sometimes felt headaches or dizziness.

“...lha gek kerasa keringat dingin gek pet-petan niku.....Gek kulo lemes-lemes ngoten...." (P1, 60 th, SD); (P2, 60 th SD)

(" ... feeling cold sweat and dizzy ... .. keep on feeling limp ...”) (P1,60 years, Elementary School); (P2, 60 years, Elementary School)

"Riyin niku sok ngrregel, mboten saged tilem, gek rasane sirah niku mumet cekotcekot" (P3, 63 th, SD); (P4, 62th, SD); (P5, 60 th, SMP)

("I used to be trembling, couldn't sleep, then I felt dizzy") (P3, 63 years, Elementary School); (P4, 62 years, Elementary School); (P5, 60 years, Junior High School)

Then 3 participants also complained that the longer their body felt thinner.

"Gek dangu-dangu niku kulo niku kok kurus ngoten lho bu"(P1, 60 th, SD); (P3, 63 th, SD)

("Then gradually my body got thinner like that..") (P1,60 years, Elementary School); (P3, 6360 years, Elementary School)

"Lha niki soyo suwe niku celono kulo niku kok sami kendor je mbak..lha terangane tambah kuru kulo" (P5, 60 th, SMP)

("This time my pants are getting looser and it turns out I'm getting thinner ") (P5, 60 years, Junior High School)

The description of stress related to the complaints that were felt was then obtained from 2 participants who said they had experienced a decrease in blood sugar levels below normal (drop blood sugar).

"Nate kulo niku malah ngedrop gendise kulo kantun 29..." (P1, 60 th, SD)

("I even dropped it. my sugar is only 29..")(P1, 60 years, Elementary School)

"Kulo nggih nate ngedrop gendise niku bu"(P3, 63th, SD)

("I also had a decrease in blood sugar, ma'am") (P3, 63 years, Elementary School)

Meanwhile, 3 participants complained that blood sugar tends to be higher than 200 $\mathrm{mmHg}$

"Wah..gendis kulo terakhir wingi niku malah 305 e bu” (P2, 63th, SD); (P4, 62th, SD); (P5, 60th, SMP)

("Wah..my last sugar yesterday it was 305 e ma'am ") (P2, 63 years, Elementary School); (P5, 60 years, Junior High School)

\section{2) Comorbidities}

The sub-theme of stress description in type $2 \mathrm{DM}$ patients is related to comorbidities experienced by participants other than type 2 diabetes. Where based on the interview data there were 2 participants who also had comorbidities, namely hypertension and 


\section{STRADA Jurnal Ilmiah Kesehatan}

DOI: $10.30994 /$ sjik.v9i2.419

ISSN: 2252-3847 (print); 2614-350X (online)

Vol.9 No.2 November 2020 Page.1250-1257

heart disease

"Gek kulo niku nggih wedi lha kulo nggih gadah darah tinggi niku” (P2, 63th,SD)

("I'm afraid too because I also have high blood pressure") (P2, 63 years, Elementary School)

"Niki kulo berjalan 1 tahun kengning gendis niku njuk sakniki jantung e ..lha nggih njuk mremen-mremen" (P5, 60 th, SMP)

("I was exposed to diabetes for 1 year and now his heart has also been hit ... it's everywhere") (P5, 60 years, Junior High School)

\section{3) Dietary restrictions}

Stress in patients with type 2 diabetes is then related to dietary restrictions, namely related to reducing food portions and sugar consumption. Based on interviews that have been conducted on patients with type 2 diabetes, it was found that there were 2 participants who said they were afraid to eat because the doctor suggested they should reduce the portion of food.

“ Rumiyin niku dek taksih enggalan niku ngantos wedi ajeng maem lha kedah dibatesi niku... mboten angsal katah-katah" $(P 1,60$ th, SD)

("In the past, I used to be afraid to eat because I had to be limited ... not much")(P1, 60 years, Elementary School)

"Nate kulo saking wedine niku gek ngantos mboten nedi lho bu"( $P 2,63 t h, S D)$

("Once I was so scared that I didn't eat at all, you know") (P2, 63 years, Elementary School)

Then 1 participant admitted that it was heavy when it came to reducing sugar consumption

"Gek sakplokke niki kulo niku dadose sik jenenge wedang legi niku pun mboten je

bu..jane nggih berat bu soale riyin remen sanget je..." (P3, 63 th, SD)

("So far, I haven't been drinking sweet, ma'am ... actually it's hard, ma'am because

I used to like it so much ...")(P3, 63 th, Elementary School)

\section{4) Psychosocial factors.}

The sub-theme related to stress that occurs in type $2 \mathrm{DM}$ patients is the existence of psychosocial factors as expressed by participants, namely related to mind.

"Lha nggih kulo niku kepripun nggih bu, nek mikir sekedhik mawon niku kok nggih

gulane banjur inggil" (P2, 63 th, SD)

("If I think just a little, the sugar continues to be high") (P2, 63 years, Elementary School)

"Nek pikiran niku nggih jelas mbak..lha pripun gek moro-moro kok loro koyo ngene

(dengan nada tinggi) " $(P 4,62$ th, $S D)$

("If the thought is clear, miss ... how do you suddenly get sick like this (with a high tone)") (P4, 62 years, Elementary School) 


\section{STRADA Jurnal Ilmiah Kesehatan}

DOI: $10.30994 /$ sjik.v9i2.419

ISSN: 2252-3847 (print); 2614-350X (online)

Vol.9 No.2 November 2020 Page.1250-1257

The stress felt by patients due to psychological factors is feeling dissatisfied with treatment.

"Nek periksa teng puskesmas niku gek naming ngoten niku mawon obat e...gek muk

dicatet lebokke stofmap .. empun (sambil terlihat kecewa)" (P5, 60 th, SMP)

("If I check it at a community health center, that's just the medicine, and just note that the folder is inserted .. already (while looking disappointed) ") (P5, 60 years, Junior High School)

Furthermore, there were 2 participants who said recently they could not routinely control and exercise because of the corona pandemic

"Cek gendise nggih naming ten puskesmas niku je bu, naming rong wulan wingi libur

lha corona niku dadose mboten saged kontrol (sambil terlihat kecewa)....."(P1, 60 th, SD)

("Check the sugar is only at the health center, ma'am, but two months ago it was off because of the corona pandemic..so I couldn't control it (looking disappointed) ") $(P 1,60$ years, Elementary School)

"Nek olah raga jane kulo tumut aktif mbak, ning mergi onten corona niki wingi lho dadose nggih leren (sambil terlihat kecewa)" (P1, 60th, SD); (P4, 62th, SD)

("For sports, I actually participate actively, but because of this corona, you know, it turns off (while looking disappointed $) ")(P 1,60$ years, Elementary School); (P4, 62 years, Elementary School)

\section{DISCUSSION}

The description of stress in type $2 \mathrm{DM}$ patients is an inability to overcome the threats faced by human mental, physical, emotional, and spiritual. Based on research conducted by (Livana et al, 2018), that most Diabetes Mellitus patients experience stress. So that, of course, one day it can affect self-care in patients which will affect the physical health of the human being. Based on the research that has been done, the description of stress in DM patients occurs due to several things, namely perceived complaints, comorbidities, dietary restrictions, and psychosocial factors.

In this study, complaints felt by type $2 \mathrm{DM}$ patients were related to physical complaints such as body weakness, pain / dizziness, body getting thinner, as well as complaints of blood sugar both low blood sugar and blood sugar which tended to be high. According to Pratiwi et al. (2014), the physical and psychological impacts that are usually felt by DM patients are in the form of changes in body weight, changes in appetite, frequent pain, fatigue, and sleep disturbances, while psychologically DM patients will experience stress, anxiety, fear, often feel sad, feeling hopeless, helpless, useless, and hopeless. This perceived complaint is certainly very disturbing and can cause stress in patients with DM.

The existence of comorbidities experienced by some participants is also a source of stress for patients with DM. Complementary diseases experienced by several participants included hypertension and heart disease. The same opinion was also conveyed by (Rennata et al. (2014), that stress is very influential on diabetes mellitus and this can increase the hormone adrenaline which can ultimately convert glycogen reserves in the liver into glucose. So that high blood sugar levels will continuously cause various 


\section{STRADA Jurnal Ilmiah Kesehatan}

DOI: $10.30994 /$ sjik.v9i2.419

ISSN: 2252-3847 (print); 2614-350X (online)

Vol.9 No.2 November 2020 Page.1250-1257

complications of DM, including hypertension, heart disease, and even stroke.

The results of this study also raise information that dietary restrictions also affect the stress that occurs in DM patients, including reducing food portions and sugar consumption. Emotional problems that are often experienced by DM patients include denial of their disease so that they are not obedient to implementing a healthy lifestyle, irritability and frustration because of many abstinence or feeling that they have undergone various therapies but there is no change in blood sugar levels that improve, fear of complications and risk of death, saturated taking medication, or even experiencing depression (Pagita, Ismail, and Redayani 2016). This is likely related to the implementation of DM self-care management including eating restrictions that must be obeyed and implemented by the patient in the long term so that of course saturation and even stress will very likely occur.

Based on this study, other causes that also cause stress in patients with type 2 diabetes are psychosocial factors including disturbances in the mind, feeling dissatisfied with the treatment that has been undertaken, and the existence of a corona pandemic which is an obstacle in the implementation of self-care management, especially for health control and exercise routine. Aside from physical factors, psychosocial factors also affect stress events. These events can cause mood disorders. A theory explains that stress or tension will cause functional changes in neurotransmitters and intraneuronal signaling systems which ultimately cause a person to have a high risk of suffering from mood disorders (Keton et al, 2008 in Harista and Lisiswanti, 2015)

The interesting thing here is that one of the triggers for stress from the participants is due to the ongoing corona pandemic, which causes delays in routine health controls for patients. Meanwhile, regular monitoring of blood glucose levels in DM patients is an important part of disease control. According to (PERKENI 2020), a history of chronic disease has a risk of being affected more frequently and with worse complications. This chronic disease history includes hypertension, diabetes mellitus, cardiovascular disease and chronic lung disease. Especially for those with diabetes, it is the second most common comorbidity found, about $8 \%$ of cases, after hypertension and with a mortality rate three times that of patients in general. That is why limiting or postponing this routine examination is carried out because Diabetes Mellitus (DM) is a risk factor for the increasing severity of COVID-19 infection.

\section{CONCLUSION}

The conclusion of this study is that the description of stress in patients with type 2 diabetes mellitus in the implementation of self-care management includes perceived complaints, comorbidities, dietary restrictions, and the presence of psychosocial factors. Therefore, sufferers need to always understand that stress is a trigger for an increase in blood glucose levels which should be controlled with proper coping. So that the results of this study are highly recommended for health centers and health services so that in the future they can design management and health education programs for DM patients in implementing better self-care management in various conditions. Then for further researchers, research on problem solving can be carried out to reduce stress in the implementation of self-care management, especially in DM patients in order to reduce further complications. 


\section{STRADA Jurnal Ilmiah Kesehatan}

DOI: $10.30994 /$ sjik.v9i2.419

ISSN: 2252-3847 (print); 2614-350X (online)

Vol.9 No.2 November 2020 Page.1250-1257

\section{REFERENCES}

American Diabetes Association. 2010. "Standards of Medical Care in Diabetes - 2010 Position Statement." Diabates Care 33(Suppl 1): S13-61. https://care.diabetesjournals.org/content/diacare/33/Supplement_1/S11.full.pdf.

Creswell John W. 2014. Penelitian Kualitatif \& Desain Riset. Yogayakarta: Pustaka Pelajar.

Harista, Rivandi Arief, and Rika Lisiswanti. 2015. "Depresi Pada Penderita Diabetes Mellitus Tipe 2." Majority 4(9): 73-77. http://jukeunila.com/wpcontent/uploads/2016/02/13.pdf.

Kementerian Kesehatan RI. 2018. Hasil Utama RISKESDAS 2018. Jakarta.

Livana PH, Indah Permata Sari, Hermanto. 2018. "Gambaran Tingkat Stres Pasien Diabetes Mellitus.” Jurnal Perawat Indonesia 2(1): 41.

Nursalam. 2015. METODOLOGI PENELITIAN ILMU KEPERAWATAN. 4th ed. ed. Peni Puji Lestari. Jakarta. http://ners.unair.ac.id/materikuliah/32Metodologi_Nursalam_EDISI 4-21 NOV.pdf.

Pagita, Dian Tri, R. Irawati Ismail, and Petrin Redayani. 2016. "Hubungan Gangguan Depresi Dengan Kualitas Hidup Pasien Diabetes Mellitus Tipe 2 Di Poliklinik Endokrin Rumah Sakit Cipto Mangunkusumo.” Journal Of The Indonesian Medical Association 66(10): 465-72.

PERKENI. 2020. "Pengurus Besar Perkumpulan Endokrinologi Indonesia ( PB PERKENI )." The Indonesian Society of Endocrinology: 1-5.

Pratiwi, Pebi, Gustop Amatiria, and Mashaurani Yamin. 2014. "Pengaruh Stress Terhadap Kadar Gula Darah Sewaktu Pada Pasien Diabetes Melitus." Jurnal Kesehatan 5(1): 11-16. https://ejurnal.poltekkes-tjk.ac.id/index.php/JK/article/view/59.

Rennata, Rezza Agus, Niken Safitri, and Dyan Kusumaningrum. 2014. "HUBUNGAN ANTARA DUKUNGAN SOSIAL KELUARGA DAN STRES EMOSIONAL DI PERSATUAN DIABETES INDONESIA (PERSADIA) UNIT RUMAH SAKIT PANTI WILASA CITARUM SEMARANG.” Keperawatan Komunitas 2: 87-93.

Sandelowski, Margarete. 2000. "Focus on Research Methods: Whatever Happened to Qualitative Description?" Research in Nursing and Health 23(4): 334-40. https://onlinelibrary.wiley.com/doi/epdf/10.1002/1098-

240X\%28200008\%2923\%3A4\%3C334\%3A\%3AAID-NUR9\%3E3.0.CO\%3B2-G.

Septiar, Handaka Ekaningputra, and Pinasti Utami. 2015. "Pengaruh Konseling Farmasis Terhadap Kualitas Hidup Dan Kadar Gula Darah Pada Pasien Diabetes Mellitus Tipe 2 Di Puskesmas Gedong Tengen Periode Maret-Mei 2014." FJurnal Farmasi Sains dan Praktis 1(1): 29-34. http://repository.umy.ac.id/handle/123456789/1989.

Setyorini, Andri. 2017. "Stres Dan Koping Pada Pasien Dengan DM Tipe 2 Dalam Pelaksanaan Manajemen Diet Di Wilayah Puskesmas Banguntapan II Kabupaten Bantul." Health Sciences and Pharmacy Journal 1(1): 1.

Smeltzer, S, C \& Bare, B, G. 2010. "Buku Ajar Keperawatan Medikal Bedah Brunner \& Suddarth Edisi 8 Vol 3."

WHO. 2016. "Global Report on Diabetes." In , 6-86. http://www.who.int/about/licensing/copyright_form/index.html\%0Ahttp://www.who.i nt/about/licensing/copyright_form/index.html\%0Ahttps://apps.who.int/iris/handle/106 65/204871\%0Ahttp://www.who.int/about/licensing/.

Widodo, Agus. 2013. "Stress Pada Penderita Diabetes Melitus Tipe-2 Dalam Melaksanakan Program Diet Di Klinik Penyakit Dalam RSUP Dr. Kariadi Semarang." Medica Hospitalia : Journal of Clinical Medicine 1(1): 53-56. 